\section{THE ECOTOURISTIC POTENTIAL OF THE MORPHOLOGIC RESOURCES IN SOME PROTECTED AREAS. CASE STUDIES: Hăşmaş-cheile Bicazului National Park And Domogled-valea Cernei National Park [The Romanian Garpathians] \\ MIHAELA VERGA1, University of Bucharest, Romania MIOARA CLIUS', University of Bucharest, Romania \\ Abstract:}

Protected areas are the territorial units' most favorable for ecotourism. This is simply because of the opportunities they offer for the kind of economic efficiency associated with the rational exploitation of their resources, optimizing the relationship between the natural landscape and human activities. Relief items, with potential for developing eco-touristic activities, are represented by a variety of forms - the most abandant are those with karst origins - in national parks such as Hasmas-Cheile Bicazului and Domogled-Valea Cernei. They are also representatives of how morphological resources can be exploited through tourism with low impact on the environment and with consistent contributions to conservation of natural heritage.

\section{Introduction}

The term eco-tourism refers, on the one hand, to a concept based on a number of principles, and on the other hand, pragmatically speaking, to a specific market segment. Eco-tourism, the concept, should have at lEast two dimensions: durability of natural resources and the participation of the local communities in the development of projects [1].

The economic boom of the last few decades has, as one of its worst consequences, shown a massive human impact on the environment particularly on those areas of special natural beauty. This process is also present in Romania - a country which has just entered the European Union (in 2007). This affiliation has obligated the central and local authorities to confer bigger importance and, therefore, funds, to projects of durability management for natural protectorates. Eco-tourism, through its components: protection, education and durable economic development, represents a solution. But this kind of exploitation has to be made only after qualitative and quantitative evaluations of the natural resources themselves as well as identification of the kind of economic activities that are benign enough for the species and the areas protected.

The two national parks, Hasmas-Cheile Bicazului and Domogled-Valea Cernei, chosen in this comparative study, are somehow similar in terms of location. They display their scenery exclusively in the mountain area of the Romanian Carpathians. The presence in their boundary of vast karst surfaces, provides high morphologic potential, with important eco-touristic valences, low developed touristic under structure, low accessibility and human pressure, and a high degree of rurality. The high eco-touristic potential is enriched in both national parks with eco-systems that have great scientific values, as well as with climatic characteristics relatively mild for such mountainous spaces, not to mention the attractiveness of their landscapes. All these elements combine in a mosaic of magnificence, to which, of course, the element of natural beauty is also added.

Among the main concerns of the parks' managements, alongside the conservation of biodiversity and the maintenance of natural structure, comes the promotion of ecologic tourism as the main form of economic exploitation for such protected spaces [2].

\section{Background of selected sites}

The Hasmas - Cheile Bicazului National Park comprises a big part from the surface of Hasmas Mountains, being located in the centre of the East part of the Romanian Carpathians. The park has been built in 1990, but it functions in the actual limits, with a total area of 6.575 ha just from 2003.

The major arguments that have justified the constitution of a National Park endorse:

- The geologic and geographic originality of 
Hasmas Mountains, represented by its various picturesque landscapes, many of which are related to the presence of limestone and dolomites (figure 1a), which generate specific karst formations;

- The large diversity of flora and fauna, flavoured by the diversity of climatic and stationing conditions;

- The great expansion of the forest, mostly natural, with equally large industrial and ecologic values.

- The absence of permanent entropic habitats, hence, the limited use of the place, (only seasonal -especially summer), which is the reason behind both its highly preserved natural beauty and its highly needed conservational legislations that may protect this beauty.

The spatial structure of the park has been determined by the unfolding of the two main morphologic components, endorsed for protection:

* Curmăturii Peak, from the West part of Hasmas Mountains, approximately $30 \mathrm{~km}$ long, with impressive calcareous steeps and wide range of karst formations: pits, caves, dolinas, uvals, thorns, lapies;

* Bicazului Gorges, which centrally penetrate, from West to East of Hasmas Mountains, approximately $8 \mathrm{~km}$ long and 300-600 $\mathrm{m}$ deep, when compared to the level of the surrounding peaks. It has steep walls, penetrated by the tributary rivers of Bicaz, and by other sectors of the wild gorges (Bicăjelului, Licaşului, Lapoşului, Şugăului); upstream the gorges. It is also quite remarkable scenery on Bicaz Valley Rosu Lake which is formed by the natural blocking of the river itself. By genesis, the dynamic beauty of this scenery is quite unique in the whole country particularly when viewed with the contrasting landscape in the middle of the mountains.

The Domogled-Valea Cernei National Park, situated in the South-Western part of Romania, was established in 1990 and having its own administration in 2003. It unfolds on the territory of three districts: Caraş Severin, Mehedinți and Gorj occupying a surface area of about 61.211 ha. Geographically speaking, the national park covers the Cerna river basin which is superposed on the West by the Godeanu Mountains massif and the Cerna Mountains and on the East by Vâlcan and Mehedinţi Mountains. In its ensemble, the watershed basin of Cerna is dominated by two groups of rocks [3]: metamorphic $(61 \%)$ and sedimentary (29\%), granites ( $9 \%$ ) and ofiolites (1\%) being also present (figure $1 \mathrm{~b}$ ).

The diversity of landscapes, unique thermal caves, thermo-mineral springs, as well as the endemic and rare flora and fauna comine to offer a unique and special experience for all visitors. Most importantly, of course, with huge tourist potential, are the landscapes. These include calcareous slopes, with the Black Pine of Banat (Pinus nigra ssp. banatica) [4], canyons carved by streams, calcareous peaks with sub-Mediterranean vegetation, vast beech forests, high alpine meadows, mountain reservoirs, and calcareous gorges and precipices. 

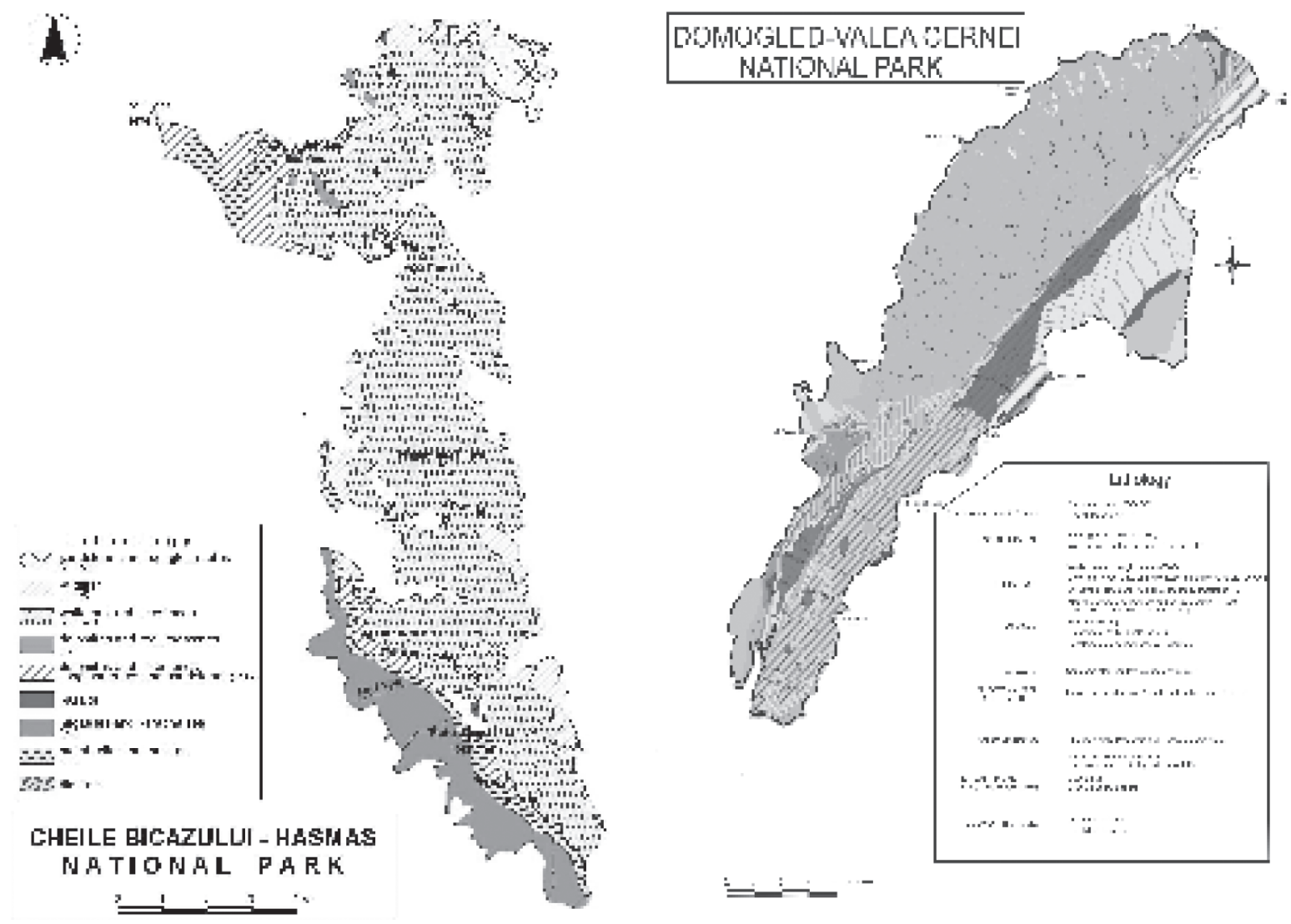

\section{Materials and methods:}

The morphological assessment of these protected areas, necessary to formulate some exploitation strategies for their safe development, involves the identification, inventory and description of those relief-forms capable, by location and physiognomy, of attracting and sustaining tourism. These operations were carried out taking into account the methodology of identification and evaluation of geomorphosites [5] the degree of tourists' interests, accessibility and relevance. In the same period, a questionnaire was made and performed by tourists visting the two national parks.

Both, first-hand field observations, and the processing of cartographic materials trough GIS programs, have allowed us to identify the areas with greater morphologic potential for eco-touristism on a relenace scale. We used, as information sources for digital processing, geological maps (1:200 000 scale), detailed topographic maps (1:25 000 scale) with 5 meters equidistance of the level curves and aerial images (1:5000 scale). In the beginning, we formulated the digital model of the land elevation. Then, a map was drawn with geomorphosital spatial distribution. Each of them receives a grade of relevance/ importance for tourism, and the outcome was a map with quantitative and qualitative elements.

At the end, we superposed the three maps and by using thematic levels and multiple interrogations, we identified the areas with high relevance grades.

\section{Results and discussion}

The mountain units included in the two national parks offer genetically different aspects. Thus Hasmas Mountains represent a large suspended synclinal cross section by the Bicaz Valley and Cerna Valley which are run along of a corridor of tectonic collapse. The large amount of limestones and dolomites represent the common aspects in both protected areas, with many morphologic similarities. For the karst surfaces, at a detailed level, a series of exo-karstic mezzo and micro forms were identified: large scale clines and depressions with karstic 
origins (dolinas, karst valleys), karst contact depressions and gorges. Related to the presence of calcareous stones, or because of tectonics (in the case of Cerna Valley), we can notice, in the case of steep valleys, lithologic and structural rapids, generating spectacular water-falls. The endo-karstic forms are also present in Cerna Valley, dimensionally small, but with peculiarity specific to the subterranean circulation of the thermal waters present in the region. The suspended position relating to the actual hydrographical system of certain subterranean holes are richly reinforced, but mostly closed to tourism because of their scientific significance. They complete the series of karstic formationss representing perhaps the highest morphologic potential in the two territorial unities.

(a)

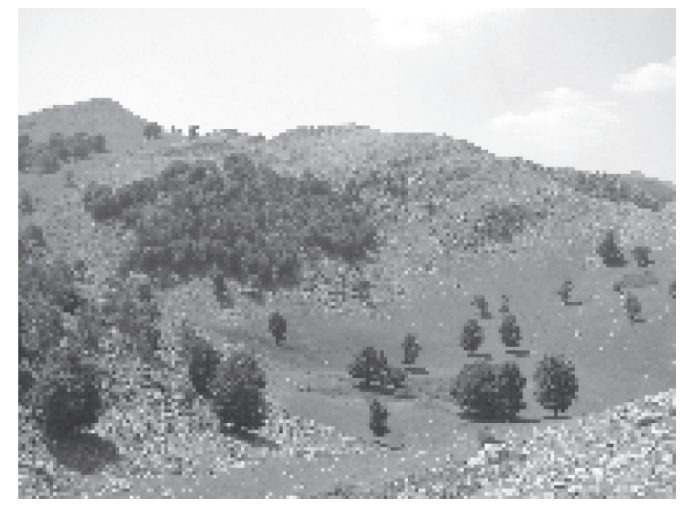

(b)

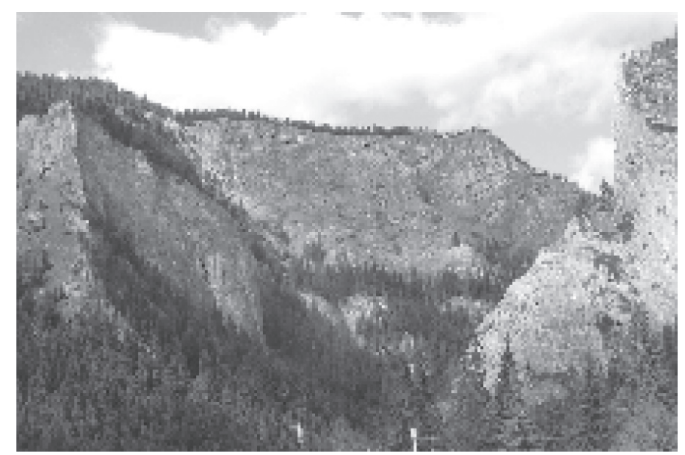

Figure 2. Geomorphosites in the two national parks: (a) Crovu

Mare Depression, (b) Southern slope of Suhardui Mic

In a complementary way, on the calcareous stones, but also on other rock types (sedimentary, ancient volcanic) desegregation relief appears, with erosion witnesses, peaks, funnels, huge detritus accumulations which look like cones, rock rivers or even trains of detritus.

Grouping of spatial forms of relief in terms of touristic values, allowed the identification and delimitation of areas of interest (figure 3), for which we established the attractiveness and accessibility scale, as follows:

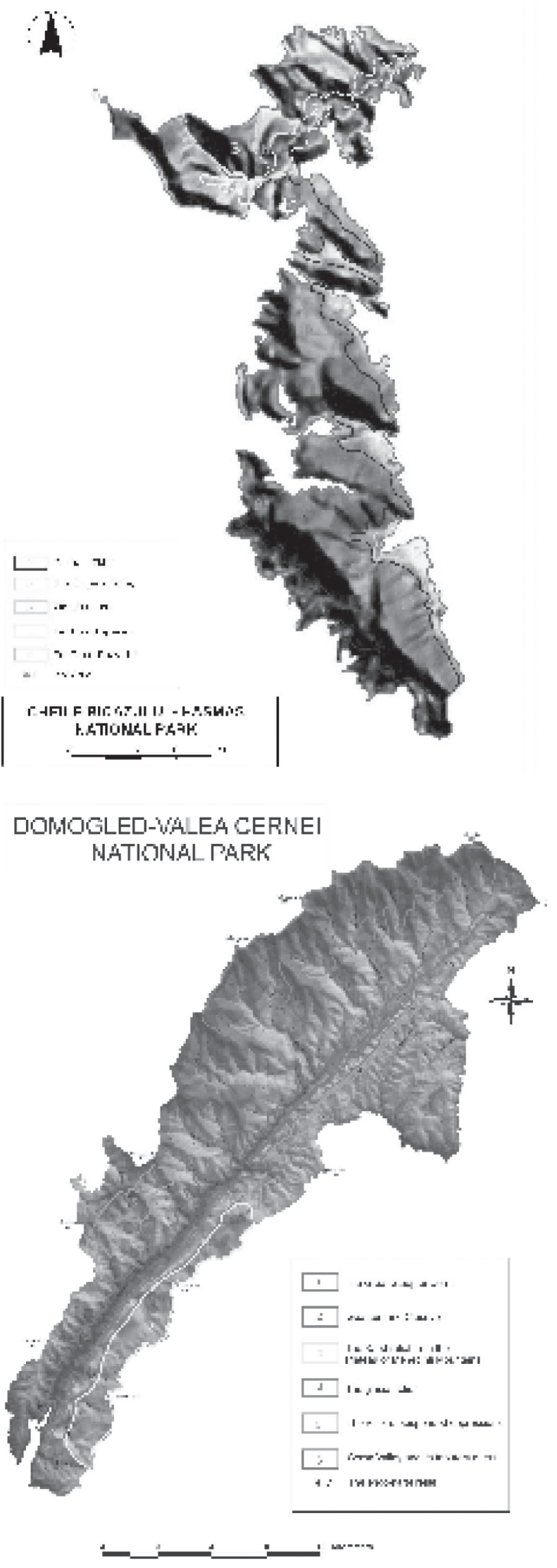

Figure 3. Morphological units with turistic value 


\section{A. Hasmas - Cheile Bicazului National Park}

1. Curmăturii Ridge represents the main peak of Hasmas Mountains, relatively unitary, with the aspect of a plateau at $1500-1700 \mathrm{~m}$ altitude, shaped in calcareous stones and dolomite. From it, numerous subordinate peaks emerge, equally levelled, which complete the orographic system. The unexpected sharp calcareous plateaus extend towards the East by a long steep, with a level difference of $400 \mathrm{~m}$ and a very sinuous contour. The detailed relief is distinguishable by the abundance of exo-karsts forms (lapies, dolinas) and the presence of some isolated rocks like Piatra Singuratică [6]. Attractiveness is very big while accessibility is low. Towards the high part of Hasmas Mountains, access can be made in more directions, using some well-known tourist routes.

2. Bicaz Gorges and the Valley is one of the most spectacular valleys inthe OrientalCarpathians. Itrepresents a succession of narrowings forming gorges, and then widened, with the aspect of inter-mountain basins. Between Rosu Lake and Bicaz-Chei Village, the narroWest and the deepest valley sectors unfold - Bicazului Gorges, with $50 \mathrm{~m}$ minimum width. The almost vertical rocky steeps reach $400 \mathrm{~m}$ emerge in which caves have emerged (Munticelul) as well as water falls (Vălul Miresei). Both tourist attractiveness, and accessibility are very high. Bicazului Gorges are longitudinal, crossed by a modernized road between Bicaz and Gheorghieni. Numerous alpinism lines, with a high difficulty degree, have been arranged on the rocky slopes from Bicaz Gorges.

3. Suhard Mountain is formed out of two peaks: Suhardul Mare (1 $506 \mathrm{~m})$, not very spectacular, with a sky track arranged on the South-Eastern side (2050 m long, $550 \mathrm{~m}$ level difference), and Suhardul Mic (1 $352 \mathrm{~m}$ ) (figure 2b), imposing by its massive block form, and seems cut like a plateau in its superior part. Attractiveness is very high and accessibility is low. Access is limited to pedestrians, both on the lines that come from Rosu Lake, and on forest roads from Cupasului Valley. On the Southern wall of Suhardul Mic, alpinism lines are also arranged.
4. Lacul Rosu Depression is peripheral, dominated by imposing rocky peaks: Muntele Ucigaşul, Muntele Suhard. Both attractiveness and accessibility, in this instance, are quite high. Rosu Lake health-resort is served by the modernised road called Bicaz - Gheorgheni.

5. Trei Fantani Depression laid on Bicajel River, at 900$1000 \mathrm{~m}$ high. It's dominated by the calcareous steep of Curmatura Peak (West). Attractiveness is high, and accessibility is moderate. The few villages situated here are related to the peripheral areas by a non-modernised road, with local interest. A few paths with tourist marks emerge from it; they climb towards the high area of Hasmas Mountains.

7. Endokarst. Some caves and pits have been inventoried [6]. All of them are small in dimension. Attractiveness is very high, but accessibility is much reduced. There is no prepared caves for tourists. Some caves have even been entirely secured (Peştera Munticelul).

\section{B. Domogled - Valea Cernei National Park}

1. The Great Steep of Cerna unfolds without interruption between Pecinişca and Arşasca Valleys, with a level difference of about $300-850 \mathrm{~m}$ and big slopes of about $40^{\circ}-60^{\circ}$, reaching an angel as sharp as $90^{\circ}$ in places. It is interrupted by suspended valleys or by valleys with gorges' aspect. It has numerous pointed cliffs, towers and structural forms. It has a Nordic and Nord-West exposure, and in its superior part associations of Pinus Nigra ssp. banatica are developed. Attractiveness is very high while accessibility is between low and very low. Touristic lines, which connect Cerna Valley to the peak of Mehedinti Mountains, penetrate this steep. There are some arrangements of lines for alpinism, canoe.

2. Geanțuri and Ciuceve are limestone lines sectors situated parallelly on the left as well as the right of Cerna's course, in the superior sector. Inside of them, tourism potential is increased by the presence of caves with small dimensions. In the superior sector of Ciuceve, there are two points of touris attraction. Firsly, the Cernişoarei Gorges and Cerna Intermittent Springs (the 
biggest resurgence of limestone in the country). Secondly, in the superior sector of Geanturi, at the exit of Cerna towards the basin from Cerna village, Corcoaiei Gorges are situated. Attractiveness is very high whil accessibility is between low and very low. A part of the touristic lines which connect Cerna Valley with the peaks of Godeanu and Mehedinti Mountains, or with the Oslea Mountain, cross this limestone steeps, but only in the areas in which the valleys have managed to cut them.

3. The Karst Relief from the Plateau of Mehedinti Mountains. Here (in the South of Arsasca Valley) the biggest and the most impressive karst depressions' altitude in the Romanian Carpathians have developed (Poiana Beletina, Poiana Mare, Crovu Mare, Crovu Medved s.o.), (figure 2a) karst valleys (Muşuroane, Ţăsnei), dry valleys, dolinas, uvalas, clays, karst peaks (Stan's Peak), fields of lapies. Attractiveness is very high and accessibility is low. The big level difference between the two plateauunits is the one which makes access difficult.

4. The glacial relief is represented by simple and complex glacial basins, even glacial valleys with all the specific associated micro-forms, developed at the sources of the rivers tributary on the right side of Cerna. Their spectacularity is lesser than in other mountain units in the Carpathians. This is because of the very thin vegetational cover (caused by the softer climate and Southern exposure), masking the glacial and periglacial formations underneath, which, otherwise, would be very attractive. Attractiveness, in this instance, is high and accessibility is low. There are few, but badly marked, tourist lines.

5. The relief of suspended depressions. Both in Cerna and in Mehedinti Mountains (better identified by human utilisation of the North part of Arsasca valley) are a series of depressions situated at around 750-1100 $\mathrm{m}$ high, between the main peaks and an alignment of limestone lines which accompany Cerna valley. The dwellings and even the hamlet are remarkable in features here (Dobraia, Prisacina, Scărişoara, Iuți). The houses dispersed on the peaks are surrounded by hays, orchards and even little yards. From inside them, the scenery towards the superior level of Cerna basin is quite spectacular. Attractiveness is high as well as accessibility. These depressions have denser habitational values, and are connected through the peripheral areas (Belareca Valley for Cerna Mountains and Mehedinti Plateau for the mountains with the same name) by numerous paths (most of which are unmarked), or by forest roads.

6. Cerna Valley and its tributary rivers present (from a tourist point of view) the biggest economic potential, because of its impressive landscapes (calcareous steeps, gorge sectors and rapids). Roşețu (20 m water fall) and Vânturătoarea (45 m water fall), and various other cataracts present there are other attraction points. Attractiveness is high (for the tributary rivers) and very high (for Cerna River) and accessibility is also high and very high. Access is made directly by the road which accompanies Cerna (modernized until km 27 and not modernized upstream).

7. The endo-karst relief. In Cerna basin there are 887 caves [7]. From these, only 23 have lengths bigger than $200 \mathrm{~m}$, five are influenced by thermals and just one is considered as being important for tourism (Haiducilor Grotto). The most spectacular cave-form in Cerna basin, is the Ion Bârzoni Cave. Attractiveness is high, with consideration of the caves' sheer number, and their thermal influence, but is also low with consideration of the lack of speleothermes in them.

\section{Conclusion and suggestion}

This qualitative and quantitative evaluation of the morphologic potential of the two national parks from Romania will be filled with works that relate to the other components of their natural presence: geology, hydrology, climate and biodiversity. Another objective is the improvement of infrastructure tourististic preparations according to the national eco-touristic standards. In this regard, it is necessary to develop the bellevue points and establish redrawing touristy paths, which must be directed 
through the areas of geomorphosites concentration. Another direction for a good management of these areas, is that they should include accurate and comprehensive information centres in response to the tourist's streams. Financial rewards gained by developing eco-tourism in these two national parks can be used to support economic and social development of local communities.

\section{References}

1.D. Fennell, Ecotourism, Routledge PH, London, 2008, p. 280.

2.R.N.P. Romsilva, Pădurile României. Parcuri naționale și parcuri naturale, Bucureşti, 2004, p.243.

3.I. Povară, Studiu fizico-geografic al bazinului hidrografic Cerna cu privire specială asupra hidrologiei carstice, Teză de doctorat, Univ. din Bucureşti, 1997, p. 216.

4.M. Pătroescu and co., Banat blak pine forests NATURA 2000 SITE, Ed. Brumar, Timişoara, 2008, p. 353.

5. E. Reynard, M. Panizza, Geomorphosites: definition, assessment and mapping. An introduction, Géomorphologie, relief, processus, environnement, $8,3,2005$, p. $177-180$

6. I. Bojoi, Formarea depresiunilor carstice în legătură cu etapele de evoluție paleogeomorfologică a Masivului Hăghimaș, An. Univ. Al. I. Cuza, Iaşi,1988, p.57.

7.C. Goran, Catalogul sistematic al peșterilor din Romania, Ed. CNEFS, Bucureşti, 1982, p. 498. 